\title{
O analiză semantică a vocii duale într-un stil literar ${ }^{\dagger}$
}

\author{
Ștefan Oltean* \\ Facultatea de Litere, Universitatea „Babeș-Bolyai”, Str. Horea 31, 400202 Cluj-Napoca, România
}

\section{Despre articol}

Istoric:

Primit 17 noiembrie 2015

Acceptat 26 noiembrie 2015

Publicat 12 februarie 2016

Cuvinte-cheie:

voce duală

discurs

\begin{abstract}
Rezumat
Lucrarea 1̂și propune să dea seamă de vocea duală articulată de discursului indirect liber (DIL), un mod discursiv întrebuințat cu precădere în proza narativă pentru reprezentarea evenimentelor verbale și a evenimentelor mentale verbale sau nonverbale (vezi Oltean, 1993). Mai întîi vom discuta problema conceptualizării discursului indirect liber, fără însă a intra în detalii privind deosebirile dintre acesta și discursul direct (DD) sau cel indirect (DI) (vezi, pentru acest aspect, Ehrlich, 1990; McHale, 1978; Oltean, 1993). Apoi vom aborda problema vocii duale cuplate cu modul discursiv în discuție, mai apoi vom schița cadrul teoretic, iar în final vom descrie forma logică a unui fragment de DIL selectat din literatura narativă de limbă engleză, în scopul specificării valenței amintite a procedeului.
\end{abstract}

\section{Introducere}

Discursul indirect liber (DIL) este un mod discursiv întrebuinţat cu precădere în proza narativă pentru reprezentarea evenimentelor verbale și a evenimentelor mentale verbale sau nonverbale. Abordările variate au condus la conceptualizări diferite ale DIL, ele vizînd fie caracteristicile sale lingvistice, fie funcțiile sale semantice sau pragmatice. Exceptînd însă contribuția lui Doron (1991) și Oltean (2003), nu s-a fost propus, pînă în momentul de față, o formalizare explicită a naturii duale a procedeului.

În cele ce urmează, vom oferi, mai întîi, o scurtă caracterizare a DIL (vezi, de asemenea, McHale, 1978 și 1983; Oltean, 1993; Ehrlich, 1990; și Flundernik, 1999), apoi vom aborda problema vocii duale cuplate cu acest mod discursiv, mai apoi vom schița cadrul analitic, iar în final vom propune o analiză semantică a unei propoziții redactate în DIL. După opinia noastră, DIL nu este, în principiu, un mod de „raportare” a discursului, ci, în esență, unul de „reprezentare”-categorie mai largă ce se aplică nu numai redării evenimentelor verbale, ci și evenimentelor mentale nonverbale. Datele pentru articol constau din fragmente selectate din texte literare scrise de Virginia Woolf (To the Lighthouse "Spre far" și Mrs Dalloway „Doamna Dalloway”), D.H. Lawrence (The Rainbow „Curcubeul” și Women in Love „Femei îndrăgostite”) și Doris Lessing (To Room Nineteen „Camera 19”).

În comparaţie cu alte moduri discursive, DIL prezintă o structură atipică: el păstrează sintaxa originară a discursului direct (autonomie sintactică, ilustrată în (1) de inversiunea verb auxiliar/subiect, în limba engleză), dar este marcat sub raport temporal și al persoanei asemenea discursului indirect; el are, așadar, o natura „mixtă” (Kuno, 1986), care a reprezentat o permanentă provocare pentru lingviști și stilisticieni și a generat un număr impresionant de conceptualizări. Această particularitate este reperabilă în exemplul de mai jos (DIL este redat în caractere cursive), selectat din romanul The Rainbow „Curcubeul” (Lawrence, 1934, p. 10):

(1) Why should the curate's children inevitably take precedence over her own children...? It was education and experience, she decided.

„De ce să aibă copiii preotului în mod inevitabil un ascendent față de copiii ei...? Se datora educației și experienței, hotărî ea."

\footnotetext{
${ }^{\dagger}$ Elemente din acest articol au apărut și în lucrările mele $A$ Survey of the Pragmatic and Referential Functions of Free Indirect Discourse (Oltean, 1993) și On the bivocal nature of free indirect discourse (Oltean, 2003).

*Adresă de corespondență: stefan.oltean@ubbcluj.ro.
} 
Marcarea în contextul verbal imediat a DIL se poate face prin elemente parantetice ${ }^{a}$ conținînd verbe de comunicare (to say „a spune”, to ask „a întreba”, to answer „a răspunde” etc.), diverse verbe psihologice sau verbe sentiendi (to think "a gîndi”, to feel „a simți”, to wonder „a se întreba”, to hear „a auzi” etc.), dar asemenea expresii nu sînt obligatorii. Atunci însă cînd sînt prezente, ele sînt exterioare structurii în DIL, fiind separate fie prin virgulă (vezi she decided „hotărî ea” în exemplul de mai sus), fie prin paranteze, cum ilustrează exemplul următor din Mrs Dalloway „Doamna Dalloway” (Woolf, 1964, p. 37), şi se numesc predicate/structuri controloare:

(2) But this question of love (she thought, putting her coat away), this falling in love with women. „Dar chestiunea aceasta a iubirii (se gîndi ea, scoțindu-și mantoul), iubirea aceasta pentru femei."

Elementele de acest gen pot fi dislocate în poziție medială sau finală în cadrul frazei, iar în calitatea lor de comentarii despre evenimentele verbale sau mentale reprezentate ele nu pot avea formă interogativă. $\mathrm{O}$ asemenea structură (întrebare) este însă posibilă în secțiunea redactată în DIL_fapt pe care îl asociem cu autonomia sintactică a enunțurilor acestuia — sau poate marca întreaga frază în cazul dislocării paranteticelor în poziție medială. Fenomenul sugerează că formulele parantetice sînt exterioare structurii propriuzise în DIL ${ }^{1}$. Imperativele propriu-zise par a fi excluse din DIL în limba engleză sau cel puțin statutul lor discursiv este ambiguu, în sensul că ele ar putea fi considerate la fel de bine drept structuri în discursul direct. În consecință, (3) și (5) sînt inacceptabile ca enunțuri în DIL în limba engleză (ele ar trebui să fie declarative; (5) ar fi, totuși, acceptabil ca discurs direct dacă s-ar ignora absența semnelor citării), (7) are un statut discursiv ambiguu (imperativ în DIL sau, mai degrabă—dată fiind imposibilitatea co-indexării pronumelor-în discursul direct), în timp ce (4) și (6), din Mrs Dalloway „Doamna Dalloway” (Woolf, 1964, p. 41) și, respectiv, din To the Lighthouse "Spre far” (Woolf, 1932, p. 119), sînt acceptabile (vezi Oltean, 1993):

(3) *What would he think when he came back, did she wonder?

* "Oare ce va crede cînd se va inapoia, se întrebă ea?”

(4) What would he think, she wondered, when he came back?

"Oare ce va crede, se întrebă ea, cînd se va înapoia?"

(5) How did she $\mathrm{i}_{\mathrm{i}}$ manage these things in the depth of the country, ask her $\mathrm{*}_{\mathrm{*}_{\mathrm{i}} \mathrm{j}}{ }^{2}$. "Cum reuşea $\left[e a_{\mathrm{i}}\right]$ astfel de lucruri in acest fund de țară? întreab-o [pe ea $\left.\mathrm{*}_{\mathrm{i} / \mathrm{j}}\right]$."

(6) How did she $\mathrm{i}_{\mathrm{i}}$ manage these things in the depth of the country? he asked her $\mathrm{r}_{\mathrm{i}}$. „Cum reuşea $\left[e a_{\mathrm{i}}\right]$ astfel de lucruri în acest fund de țară? o întrebă $\left[\mathrm{pe} \mathrm{ea}_{\mathrm{i}}\right]$."

(7) Well then let her ${ }_{\mathrm{i}}$ go and be damned to her, she $\mathrm{j}_{\mathrm{j} / *_{\mathrm{i}}}$ told herself. „Bine, atunci ducă-se și ea $a_{\mathrm{i}}, n$-avea decît să se ducă la dracu!, își spuse ea $\mathrm{j}_{\mathrm{j} / *_{\mathrm{i}} . ”}$

Avantajul delimitării DIL de alți constituenți frazali este demonstrată de însăși complexitatea structurală debordantă a acestuia, fapt care indică productivitatea unui tip discursiv ce se bucură de o relativă autonomie sintactică.

După cum reiese din cele arătate mai sus, DIL are o natură „mixtă” (Kuno, 1986). Pe de altă parte, el poate prezenta mărcile discursului direct, care trimit la personaj sau protagonist prin evocarea unei alte

${ }^{a}$ Elementele parantetice constau din expresii „controloare” corespunzînd contextului naratorial, care servesc orientării cititorului cu privire la locutorul al cărui discurs (exterior sau interior) este reprezentat în DIL, sau la subiectul a cărui perspectivă sau stare interioară este înfățișată: spre exemplu, $x$ a spus, a întrebat, a simțtit, s-a gîndit, s-a întrebat, și-a imaginat etc. Prezența lor nu este obligatorie.

${ }^{1}$ Vezi însă Kuno (1986), care, contrastînd „discursul mixt” [„,blended discourse”] din japoneză cu „discursul cvasi-indirect” (adică, DIL) din engleză, tinde să trateze elementele contigue din contextul imediat, în limba engleză, drept parte a discursului cvasi-indirect. Vezi de asemenea abordarea DIL de către Susan Ehrlich (1990), unde rolul expresiilor parantetice este reconsiderat din perspectiva analizei discursului.

${ }^{2}$ Indicele marchează identitatea (co-indexare) sau nonidentitatea referinței pronumelor personale din propoziția principală cu acelea din structura parantetică. În primul caz (identitate), frazele sînt acceptabile ca DIL; în cazul al doilea (nonidentitate), ele nu îndeplinesc o asemenea condiție. 
voci sau perspective, diferită de cea naratorială; acest aspect implică de asemenea ocurența de elemente lexicale idiosincrasice, cum ar fi colocvialisme, cuvinte argotice, sau elemente lexicale aparținînd unor variate registre (neliterare) ale vorbirii, precum și prezența expresiilor indexicale this „acesta”, aici „here”, now „acum”, al limbajului afectiv, al exclamaţiilor, sau al inversiunii subiect/verb auxiliary în limba engleză. Pe de altă parte, marcarea DIL asemenea discursului indirect se poate interpreta ca o trimitere la narator, cel puțin ca emițător „formal” (Ehrlich, 1990, p. 9) (persoana a treia a pronumelor cu deictică de persoana întîi, sistem de timpuri verbale bazat pe timpul trecut în limba engleză, cu o posibilă deictică de present sau chiar viitor). Conjugarea de trăsături ce susțin „oblicitatea”b (Strauch, 1974) enunțurilor în DIL (adică marcarea sub raportul persoanei și al timpului verbal) cu prezența elementelor care marchează vocea personajului semnalează bivocalitatea (Bakhtin, 1973) sau polivocalitatea DIL (McHale, 1978) și, implicit, perspectiva duală pe care acesta o exprimă. Au mai fost sugerate particularități semantice, cum ar fi prezența simultană a perspectivei exterioare și interioare (vezi Cohn, 1978), iar semnificația unor factori sau fenomene semantice și pragmatice majore, cum ar fi ironia și contextul verbal, a fost reevaluată (vezi Ramazani, 1988; Weinberg, 1981, 1984; McHale, 1983; Oltean, 1993). Mikhail Bakhtin [V. N. Voloshinov] (1973, p. 155) susține, în acest sens, că aspectul distinctiv al DIL constă în aceea că atît autorul, cît și personajul se exprimă simultan, că accentele și intonațiile personajului (empatie) coexistă cu accentele autorului (distanță) în cuprinsul unei singure construcții lingvistice. În plus, Moshe Ron (1981) postulează tipuri particulare de reprezentări ale „,̂ntrebărilor-ecou” în DIL, specificate sub forma dialogului incapsulat (embedded), care exprimă două acte de vorbire suprapuse-actul de vorbire „raportor” al naratorului și actul de vorbire „raportat” al personajului-și, în consecință, doi vorbitori ${ }^{3}$. În cadrul unui denmers echilibrat, Vaheed Ramazani (1988, p. 43) arată că nu trebuie exagerat rolul nici unui „indice” particular ce contribuie la percepția DIL ca „fuziune a limbajului naratorial cu cel figurat” (t.n., S,.O.), deoarece importanța relativă a acestora este dictată de fiecare caz în parte, ceea ce subliniază relevanța contextului, în timp ce în altă parte, spre exemplu, (8), din To Room Nineteen „Camera 19” (Lessing, 1981, p. 55), domină trăsăturile sintactice sau lexicale, cum ar fi exclamațiile, adverbele hiperbolizante sau inversiunea subiect/verb auxiliar.

(8) But then everyone exclaimed: Of course! How right! How was it he never thought of it before? „Dar atunci fiecare exclamă: Desigur! Cît de corect! Cum de nu se gîndise înainte la așa ceva?”

Polivocalitatea poate fi observată în următorul pasaj din To the Lighthouse „Spre far” (Woolf, 1932, p. 162163), unde ea marchează reprezentarea discursului exterior redat în DIL:

(9) They came with their brooms and pails at last; they got to work. All of a sudden, would Mrs McNabb see that the house was ready, one of the young ladies wrote; would she get this done; would she get that done; all in a hurry. They might be coming this summer.

\footnotetext{
${ }^{b}$ Fenomenul constă în transpunerea pronumelor personale și a timpurilor verbale în urma ancorării acestora la contextul raportor („Eu îțispun că”...), subînțeles și de regulă suprimat din structura enunțurilor raportate. În acest sens, în cazul discursului indirect, pronumele $e u$ devine, în funcție de identitatea raportorului desigur, $e l$ sau $e a$, raportorul fiind cel mai frecvent o altă persoană, iar timpul verbal se va modifica și el, în mod obligatoriu în engleză (trecut), opțional în română (imperfect). Astfel, dacă Ion rostește enunțul „Azi [eu] nu mă simt bine”, atunci structura în discursul indirect, care prezintă mărcile oblicității, va fi „,[Eu îți spun că] Ion a spus că în acea zi [el] nu se simțea bine”, unde [Eu îți spun că] este partea performativă, subînțeleasă, de regulă suprimată.

${ }^{3}$ Ron (1981, p. 31-32) argumentează că propoziția „What had kept her?” („Oare ce a reținut-o?”)—o întrebare ecou reprezentată prin DIL, selectată din romanul Sexus al scriitorului american Henry Miller-se poate reconstitui sub forma unui dialog între narator (Henry) și personaj (Mara), și redat ulterior în DIL:
}

Henry: What kept you? („Ce te-a reținut?”)

Mara: What kept me? („Ce m-a reținut?”)

În consecință, propoziția constă din două acte de vorbire distincte, suprapuse, produse de doi vorbitori: cel care raportează (naratorul) și cel al cărui act este raportat (personajul). Prezența ultimului este presupusă de întrebuințarea, de către primul, a pronumelui her [pe ea/o], care trimite la un referent diferit la nivelul contextului pragmatic descris în text, și anume persoana care a provocat întrebarea. 
„În cele din urmă veniră cu mături și găleți; se așternură pe treabă. Ar dori doamna McNabb să fie atît de amabilă incît să vadă de punerea la punct a casei, scrisese pe neașteptate una dintre domnişoare; ar dori ea să facă asta; ar dori ea să facă aialaltă; şi totul în grabă. S-ar putea să vină la vară."

Exemplul reprezintă discursul exterior al femeii de serviciu (dna McNabb). Polivocalitatea, vocea duală, marchează ironia dramatică ; ea este exprimată prin accentele specifice și concentrarea, de către narator, a colocvialismelor în versiunea condensată a evenimentului verbal originar. Timpurile verbale și pronumele în limba engleză susțin distanțarea naratorului faţă de autoarea scrisorii.

Polivocalitatea/bivocalitatea poate însă consta și într-o simplă identificare empatetică a naratorului cu personajul; deseori, acest tip se manifestă în reprezentarea reflecțiilor personajului, cum este cazul exemplului (10), din The Rainbow „Curcubeul” (Lawrence, 1934, p. 274):

(10) Why, ob why must one grow up, why must one inherit this heavy, numbing responsibility of living an undiscovered life? Out of the nothingness and undifferentiated mass, to make something of herself! „De ce, oare de ce trebuia omul să crească, de ce trebuia să moștenească această mare și copleșitoare responsabilitate de a trăi o viață nedescoperită? Din nimic și din această masă nediferențiată, să realizeze ceva din sine!"

În acest caz, DIL transmite empatia naratorului faţă de personajul care se autocompătimește. Exemplul ar putea sugera că vocea duală este abolită; însă chiar și într-un asemenea caz DIL prezintă semne ale naratorului: în particular, marcarea sub raportul persoanei și al timpului verbal, precum şi caracterul puternic articulat al redării stării interioare.

La polul opus, de parcă ar refuza orice generalizare, există cazuri de DIL care tind a fi univocale. Un asemenea fenomen se petrece cu precădere atunci cînd DIL, ca vehicul al conștiințtei spontane, nonreflexive, reprezintă stări mentale nonverbale sau preverbale, de regulă percepții, cum susțin Kuroda (1976) și Banfield (1982); în conformitate cu aceștia, DIL constă din unspeakable sentences „enunțuri nearticulabile”, lipsite de emițător, fiind un mod particular, sui generis, al limbajului, care nu se lasă încadrat din punct de vedere comunicațional ${ }^{4}$. Vocalizarea creează în acest caz un obiect lingvistic atribuibil numai naratorului, dar odată acceptate convențiile reprezentaționale ale limbajului și literaturii, se poate admite fără ezitare că discursul redă experiența lăuntrică a personajului, incluzînd stările sale subiective.

Statutul vocii sau al perspectivei duale este, așadar, controversat în cadrul studiilor consacrate DIL. Dat fiind acest fapt, ne propunem să dăm seama de prezența acestui fenomen printr-un demers formalist, considerînd că acesta, prin concretețea demonstrației, poate aduce clarificări. Doron (1991) oferă, întro relevantă contribuție în cadrul cadrul semanticii situaționale, prima reprezentare formală care semnalează dovezi ale perspectivei/vocii duale în DIL. Disociind punctul de vedere ca element constitutiv al

\footnotetext{
${ }^{4}$ Kuroda și Banfield elaborează o interpretare după care particularitatea semantică în discuție este definitorie pentru frazele redactate în DIL: lipsite de narrator sau emițător, frazele acestuia reprezintă o stare mentală, ceva „nearticulabil” ce nu poate fi transpus într-un cadru communicațional. Pornind de la prezența sau absența anumitor trăsături sintactice și lexicale (spre exemplu, elemente expresive, cum ar fi exclamații, repetiții, întrebări, pronume personale, deictice, timp verbal, elemente lexicale specifice), Banfield (1982) distinge DIL (acesta este noncomunicativ și expresiv, reprezentînd vorbirea sau gîndirea) de narațiunea propriu-zisă (necomunicativă, nonexpressivă) și de discurs (comunicativ, expressiv), și numește enunțurile primelor două „propoziții nearticulabile”. În timp ce narațiunea nu este nici uz comunicativ al limbajului (adică uz definit de relația eu/tu), nici expresie a subiectivității, DIL este „expresiv”, dar lipsit de emițător, pentru că elementele „subiective” sînt coreferente cu un „subiect al actului mental” la persoana a treia (Banfield, 1982, p. 18) și nu cu un locutor, a cărui marcare ar trebui să fie la persoana întîi-I „eu” (sic!). La fel, pentru Kuroda enunțurile în DIL sînt necomunicaționale, fiind puse pe seama funcției constitutive sau poetice a limbajului. Asemenea enunțuri prezintă o structură nonasertorică, de vreme ce ele nu citează sau raportează vreun discurs (exterior sau interior) al unui vorbitor originar şi nu emană de la nici un locutor. Mai mult chiar, ele nu se sprijină nici măcar pe vreun act mental intentional de evaluare a evenimentului de către personaj-fapt care ar presupune o marcare la persoana întîi-, ci reprezintă într-o manieră expresivă o stare mentală, un nivel intermediar al conștiinței, și anume conștiința spontană, nonreflexivă. Cu alte cuvinte, asemenea enunțuri creează cunoașterea unui eveniment (spre exemplu, a unei acțiuni sau stări interioare a personajului), dar sînt lipsite de „motivație semiotică” (vezi Ron, 1981) pentru că nu prezintă mărci ale transmițătorului (real sau imaginar).
} 
conținutului de atitudine, ea argumentează că unele expresii deictice sau indexice se ancorează la situația de discurs - spre exemplu, pronumele la persoana întîi și a doua, vezi (11)—, unele sînt dependente de punctul de vedere sau de perspectivă-spre exemplu, demonstrativele, deictica temporală, vezi (12), din The Rainbow „Curcubeul” (Lawrence, 1934, p. 377) —, iar altele se pot ancora atît la situația discursului cît și la perspectiva înfățișată—spre exemplu, pronumele la persoana a treia, timpurile verbale; vezi (13), din The Rainbow „Curcubeul” (Lawrence, 1934, p. 350).

(11) I hate it.

„[Eu] Detest asta.” [„Eu” este o funcție dinspre contexte înspre intensiuni; valoarea lui este dată de situația de discurs: locutorul, producătorul discursului.]

(12) She felt she must go out of this school, this torture place.

„[Ea] simțea că trebuie să părăsească această școală, acest loc de tortură”. [Valorile lui this school „această școală” şi this torture place „acest loc de tortură” sînt dependente de perspectiva personajului (Ursula), dar sînt insensibile la situația de discurs (locutor, locaţia discursului); expresia trimite la o entitate contemplată de subiectul actului mental (Ursula) —școala despre care este vorba; valoarea ei este o funcție dinspre punctul de vedere înspre intensiuni.]

(13) [a] As she returned home, she dreamed again ... her old, gorgeous dreams. [b] One of her applications was to Gillingham, in Kent...

[a] „Pe cînd se întorcea acasă $[e a]$ trăi din nou minunatele $e i$ vise de demult.” [b] „Una din cererile ei era pentru Gillingham, in Kent...” [Valoarea lui her „ea”, „ei”-Ursula) în prima propoziție este distinctă de locutor (naratorul), pronumele ancorîndu-se la situația de discurs; la fel se întîmplă şi în cazul timpului verbal-past tense „trecut”-, care se ancorează la prezentul relatării. În schimb, în propoziția a doua, de data aceasta în DIL, valoarea pronumelui her este o funcție a perspectivei înfățișate, fiind identică cu subiectul actului mental (Ursula), cum este cazul și cu timpul verbal—past tense „trecut”- care nu se ancorează la prezentul relatării, ci la punctul de vedere al personajului, avînd o valoare de prezent (starea înfățișată este simultană cu actul mental al personajului)]

Pornind de la această ultimă categorie de expresii deictice (acelea care se ancorează atît la situația de discurs cît și la perspectivă), Doron (1991) constată că pronumele la persoana a treia care funcționează ca subiecte ale stărilor de conștiință reprezentate de DIL conțin o informaţie suplimentară referitoare la gen (vezi her în (13b) -feminin, în exemplul propus) și argumentează că o asemenea informație nu poate fi pusă pe seama protagonistului/protagonistei, deoarece ea este evidentă pentru protagonist și, în consecință, ar fi trivială; referirea la sine s-ar face, într-un asemenea caz, printr-un pronume la persoana întîi, „eu” (în exemplul (13b), supra, ar fi vorba de my applications „cererile mele”, nu de her applications „cererile ei”). Pronumele în discuție sînt, așadar, mai informative decît $I$ „eu”, conchide ea (p. 59) și consideră acest fapt drept dovadă a caracterului „dual” al DIL, deoarece în timp ce vocea personajului „emană” din „punctul de vedere”, vocea naratorului, pe seama căreia trebuie pus tipul de informație în discuție, „emană din situația de discurs” (p. 60) (t.n., Ș.O.); ea este opusă perspectivei. Această ipoteză nu este însă lipsită de probleme: DIL prezintă în mod obligatoriu un pronume la persoana a treia în limba engleză-cu care se asociază perspectiva一, iar o asemenea limbă nu poate evita marcarea genului la această persoană; aşadar, forme precum she „ea”, he „el”, her „(ale) ei” etc. sînt singurele posibilităţi oferite de sistemul limbii. De asemenea, există limbi, cum ar fi maghiara, care nu prezintă disctincții de gen în pronumele la persoana a treia. În consecință, informația suplimentară referitoare la gen, prezentă în pronumele la persoana a treia în limba engleză, s-ar putea să nu fie o dovadă incontestabilă a dualităţii.

Considerăm, de aceea, că se impune găsirea unor dovezi noi ale naturii duale a DIL și ne propunem identificarea acestora prin practicarea unui tip de demers formal în anumite privințe diferit, și anume acela al semanticii modelelor teoretice sau al lumilor posibile. Ipoteza noastră este că un asemenea demers va permite captarea unor aspecte referențiale din perspectiva situațiilor propriu-zise sau a stărilor de lucruri din lumile ficțiunilor descrise de DIL, care vor documenta și mai clar problema caracterului dual al DIL. 


\section{DIL și problema referențială}

În Oltean (1993) am arătat că DIL, ca modalitate de reprezentare a discursului și a actelor mentale, este despre un act de discurs (fapt verbal) dintr-o lume a ficțiunii (discurs exterior sau interior) sau despre un act mental aparținînd conștiinței spontane, nonreflexive a personajului (fapt psihologic). Pentru a specifica însă natura duală a procedeului, se impune abordarea laturii referențiale, a valorii de adevăr sau a denotației DIL literar, deoarece bivocalitatea comportă şi un aspect referențial: dacă DIL nu este univocal, ci prezintă mărci ale naratorului alături de mărci ale personajului, atunci el descrie două lumi-o lume compatibilă, spre exemplu, cu ceea ce spune, gîndește, își imaginează personajul, și o lume în care se actualizează ceea ce relatează naratorul. În acest scop vom discuta pe scurt noțiunea de referință în cadrul semanticii modelelor teoretice și vom opera cu versiuni ale acestei semantici, cum ar fi cele prezentate în Chierchia \& McConnell-Ginet (2000) și Portner (2005), pe care le vom adapta pentru analiza aspectelor semantice sau extensionale ale DIL.

De la Gottlob Frege încoace, noțiunea de referință a fost pusă pe seama relației dintre expresiile lingvistice și denotatul lor ${ }^{5}$, întrebuințindu-se termeni precum referință, valoare semantică sau valoare de adevăr, primii doi aplicîndu-se denotației unui nume sau al unei expresii lingvistice, iar ultimul, referinței propozițiilor-situațiile sau stările de lucruri desemnate de acestea (vezi Chierchia \& McConnell-Ginet, 2000; Portner, 2005). (Referința unui nume este un obiect individual, în timp ce sensul sau intensiunea acestuia este un concept individual; referința unui predicat este un set de indivizi, iar intensiunea lui este o proprietate.) Versiunile semanticii formale în discuție permit specificarea denotației expresiilor lingvistice, inclusiv a propozițiilor/frazelor, în cadrul unui limbaj artificial numit calcul predicațional, prin intermediul căruia se propun descrieri ale reprezentărilor mentale asociate propozițiilor/frazelor, cărora apoi li se atribuie valori de adevăr printr-o funcție de interpretare [[]] în raport de mai multe coordonate, cum ar fi un model, $M$, sau o „lume” la care se referă diferitele tipuri de expresii ale limbajului-variabile, constante individuale, predicate-și o funcție $g$, prin care se atribuie valori variabilelor. Modelul este o structură abstractă care are forma $\langle U, V\rangle$, unde $U$ este domeniul, setul de indivizi sau universal discursului, iar $V$ este o funcție ce atribuie extensiuni în $U$ pentru constantele individuale și predicatele din calculul predicațional. Acesta conține un set de reguli semantice recursive care permit specificarea valorilor de adevăr ale propozițiilor relative la conținutul modelului. Dacă o propoziție $S$ este adevărată în lumea reală, atunci $[[S]]^{M, g}=1$ reprezintă formalizarea valorii sale, ceea ce ne spune că ea este adevărată relativ la un model $M$ și o funcție $g$ (vezi Chierchia \& McConnell-Ginet, 2000, p. 125); dacă ea este neadevărată sau falsă, valoarea ei este 0 . În consecință, valoarea semantică a propoziției [[S Cancelarul Germaniei este femeie $]]^{M, g}=$ 1 dacă și numai dacă după atribuirea de valori semantice relative la $M$ și $g$ elementelor lexicale și pe baza regulilor combinatorii (compoziționale) $S$ poate fi evaluat ca fiind adevărat relativ la $M$ și $g$. În virtutea regulilor semantice ale limbii engleze se poate afirma că un asemenea lucru este adevărat dacă și numai dacă $[[\text { Cancelarul Germaniei }]]^{M, g} \in[[\text { femeie }]]^{M, g}$, adică, dacă și numai dacă Cancelarul Germaniei este membru al setului de femei sau, cu alte cuvinte, al setului care reprezintă extensiunea predicatului este femeie în situaţia specificată. Dacă aceste condiţii nu sînt îndeplinite, atunci $[[S]]^{M, g}=0$.

Pe calea descrisă mai sus pot fi specificate condițiile de adevăr ale propozițiilor în funcție de valoarea semantică a componentelor acestora într-o situație dată și pot fi definite modele diferite pentru situații diferite, dar în procesul de evaluare a propoziției poate fi avută în vedere doar o singură situație. Există însă numeroase expresii lingvistice sau propoziții/fraze care reclamă o evaluare relativă la circumstanțe diferite de acelea în care sînt evaluate, cum ar fi situații din trecut, viitor, situații posibile, non-actuale sau ipotetice. Asemenea expresii descriu lumi posibile sau circumstanțe alternative, ,a way things might be, not necessarily the way they are" (Lewis, 1979, p. 84). Acestea se numesc construcții intensionale, iar extensiunea lor poate

\footnotetext{
${ }^{5}$ Vezi Chierchia \& McConnell-Ginet (2000, p. 65), care arată că în conformitate cu Frege referința unei expresii constă în ceea ce ea desemnează în cazul unei anumite întrebuințări, în timp ce sensul său este dat de maniera în care este prezentată referința.
} 
fi specificată prin coordonatele lume, $w$ (din englezescul world), și moment temporal, $t$, în raport de care pot fi atribuite valori semantice sau valori de adevăr, după cum ilustrează următoarele exemple:

(14) $[[\text { președintele Americii }]]^{w_{@}, t_{0}}=$ Barack Obama [unde $w_{@}$ este lumea reală, iar $t_{0}$, momentul actual, al enunțării]

(15) $\left[[\text { președintele Americii] }]^{w_{@}, t_{1}}=\right.$ George W. Bush [unde $t_{1}$ precedă $t_{0}$, deci $t_{1}<t_{0}$ (momentul actual, al enunțării); spre exemplu, $t_{1}=31$ octombrie 2008]

(16) $\left[[\text { președintele Americii] }]^{w_{1}, t_{0}}=\right.$ Mitt Romney [unde $t_{0}$ este momentul actual, al enunțării, iar $w_{1}$ este o lume posibilă în care Mitt Romney cîștigă alegerile]

(17) $[[\text { Mitt Romney este președinte al S.U.A. }]]^{w_{1}, t_{0}}=1$ [unde $t_{0}$ este momentul actual, al enunțării, iar $w_{1}$ este o lume posibilă în care Mitt Romney cîștigă alegerile; deci, fraza este adevărată în $w_{1}$ în momentul enunțării; cu alte cuvinte, ea este adevărată dacă și numai dacă în $w_{1}$ Mitt Romney cîștigă alegerile.]

Condițiile de adevăr se modifică, însă, în cazul propozițiilor incapsulate, complemente ale unor verbe de atitudine propozițională, cum ar fi believe „a crede”, think „a gîndi”, hope „a spera” etc., relevante pentru analiza semantică a DIL. Să luăm, în acest sens, următorul exemplu:

(18) [[Paul crede că Mitt Romney este președinte al S.U.A. $]]^{w_{@}, t_{0}}=1$ dacă și numai dacă Paul crede că Mitt Romney este președinte al S.U.A., conform principiului discitaţional al lui Tarski („థ" este adevărat dacă și numai dacă $\varphi$ ).

După cum se poate observa, valoarea de adevăr al lui (18) nu depinde de adevărul propoziției incapsulate „Mitt Romney este președinte al S.U.A.” Această propoziție este falsă, deși (18) poate fi adevărat. Paul poate crede, spre exemplu, că Mitt Romney este președinte al S.U.A. chiar dacă acesta a pierdut alegerile. Propoziției incapsulate i se acordă, în consecință, o valoare de adevăr nu în lumea în care s-a produs enunțul (lumea reală, $w_{@}$, în cazul nostru), ci într-o lume compatibilă cu ceea ce crede Paul, în care sînt actualizate convingerile sale, accesată din $w_{@}$, după cum reiese din formalizarea de mai jos:

(19) $\left[\left[\text { Paul crede că }[[\text { Mitt este președinte al S.U.A. }]]^{w_{1}, t_{0}}\right]\right]^{w_{@}, t_{0}}\left[\right.$ unde $w_{1}$ este o lume compatibilă cu ceea ce crede Paul (în această lume Mitt Romney este președinte).]

Modelul $M$ devine acum o structură care are forma $\langle W, T,<, U, V\rangle$, în care $W$ este un set de lumi, $T$ este un set de momente ordonate printr-o relație de precedență $<$ (în sensul că $t_{2}<t_{1}$ se citește ", $t_{2}$ îl precedă pe $t_{1}$ ”), $U$ este universul discursului, domeniul „cuantificării” sau setul de indivizi, iar $V$ este $o$ funcție dinspre constante individuale și predicate înspre intensiuni în $W$ și $T$ (circumstanțe) (vezi Chierchia \& McConnell-Ginet, 2000, p. 268). În particular, pentru verbele care acceptă propoziții incapsulate introduce prin „că”, cum ar fi a crede, $V$ va fi o funcție dinspre lumi și momente temporale înspre relații cu doi termeni, primul fiind un individ în $U$, iar al doilea o propoziție sau set de lumi (p. 304). Noul calculul predicațional intensional,care conține acum o funcție de interpretare diferită, de forma $[[]]^{M, w, t, g}$, va atribui o valoare de adevăr unui enunț în raport de un model și o funcție $g$, precum și o pereche lumetimp, asociind enunțul cu o propoziție care este evaluată drept adevărată sau falsă relativ la o circumstanță particulară, definită de coordonatele $w$ și $t$.

Aceste ultime precizări se vor dovedi utile pentru semantica DIL, deoarece acesta se cuplează adesea cu expresii parantetice care conțin verbe de atitudine propozițională—spre exemplu, verbe psihologice sau verbe performative, cum ar fi decide „hotărî” în (1), think „gîndi” în (2), wonder ,a se întreba” în (4), dream „visa” în (13), exclaim „exclama” în (8), ask ,întreba” în (6). Datorită faptului însă că analiza noastră vizează DIL din textul literar, coordonatele amintite mai sus, în speță coordonatele lume $(w)$ și timp $(t)$, trebuie redefinite și adaptate la circumstanțele din lumile ficțiunii, în pofida problemelor pe care le pune o abordare din perspectiva semanticii lumilor posibile a discursului ficțional (vezi Currie, 1990; Lewis, 1983; Pavel, 1986). 
Discursul ficțional presupune un act de recentrare (Ryan, 1991), de repoziționare, prin care o lume a povestirii, a ficțiunii, se substituie lumii actuale. Narațiunea ficțională poate fi astfel considerată ca un sistem alternativ de lumi cu centrul situat într-o lume posibilă în jurul căreia sînt dispuse lumi periferice accesibile din lumea centrală, referința ei depinzînd nu atît de ceea ce discursul ficțional descrie în mod explicit, cît mai degrabă de „faptele” ce definesc o lume compatibilă cu povestirea sau o lume a povestirii-o lume posibilă în accepția semanticii modale, în conformitate cu Lewis (1983) și Currie (1990, p. 62), în care ceea ce este explicit în povestire se relatează ca un „fapt cunoscut”, adică se presupune că este adevărat.

Pentru a reprezenta DIL, a cărui cuplare cu narațiunea ficțională este indiscutabilă $\breve{b}^{6}$, coordonatele vor trebui definite, așadar, în raport de circumstanțele din lumea ficțiunii sau lumile (periferice) accesibile din lumile ficțiunii. Astfel, dacă $w_{1}$ este o lume compatibilă cu ficțiunea, care se substituie lumii reale, $w_{@}$, iar $t_{1}$ este momentul relatării, atunci $w_{2}$ va fi o lume accesată din $w_{1}$, compatibilă, spre exemplu, cu ceea ce crede, visează, își imaginează etc. protagonistul (personaj) unei scene narative (vezi Figura 1). De asemenea, $t_{2}$ va desemna timpul de referințăc sau "prezentul narativ”-_timpul producerii evenimentelor ficționale” (Ehrlich, 1990, p. 64) -, iar $t_{3}$ va fi timpul evenimentului sau al stărilor de lucruri ce anterioare lui $t_{2}$. Un asemenea cadru va permite captarea, formalizarea vocii duale în exemplul selectat.

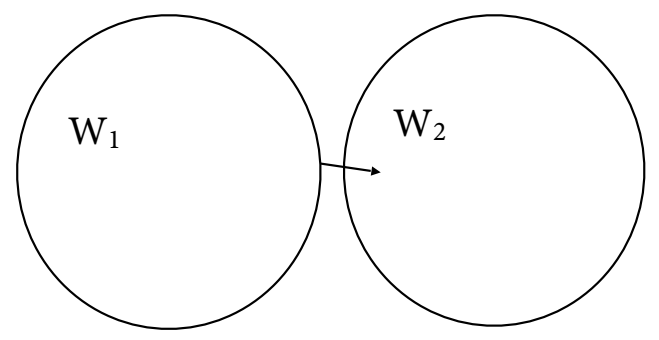

Figura 1

\section{Analiza semantică}

Multe enunțuri în DIL conțin predicate parantetice sau cu funcție de control—vezi „hotărî ea” în (1) supra. Cînd asemenea predicate nu sînt explicite, ele pot fi suplinite ținînd cont de tipul actelor de vorbire sau al actelor mentale reprezentate (întrebare, exclamație, conversație, reflecție, retrospecție etc.). Ele fac posibilă descrierea neambiguă a aspectelor referențiale prin tratarea enunțurilor redactate în DIL (fraze întregi sau fragmente de frază) drept ,complemente” ale predicatelor controloare și specificarea ulterioară a denotaţiei lor în lumile ficțiunii $\left(w_{1}\right)$ sau în lumi accesibile din lumile (centrale) ale ficțiunii $\left(w_{2}\right)$. Precizăm în acest sens că, sub raport extensional, enunțurile în DIL sau fragmente de frază în DIL (atunci cînd întreaga frază nu este redactată în DIL) pot fi considerate structuri incapsulate ${ }^{7}$ („embedded”), în pofida diferențelor sintactice sau semantice față de structurile subordonate.

În plus, predicatele parantetice controloare pot fi abordate în funcție de noțiunile de factivitate și nonfactivitate (vezi Kiparsky \& Kiparsky, 1971), cuplate cu transparența și, respectiv, opacitatea presupozițiilor complementelor lor (vezi Karttunen, 1991, p. 410). Predicatele factive includ verbe precum a-și da seama, a observa, a-și aminti ${ }^{8}$; ele presupun adevărul complementelor lor, fapt testabil prin negare, vezi (20):

${ }^{6}$ Există un consens al cercetătorilor cu privire la acest aspect. Vezi de asemenea Cohn (1978) și Fleischman (1990), care sînt de părere că DIL, chiar dacă nu se restrînge la domeniul literaturii, este, totuși, un fenomen caracteristic narațiunii ficționale.

${ }^{c}$ Avem în vedere abordarea reichenbachiană a timpului de către Ehrlich (1990, p. 61), care distinge trei momente temporale: timpul vorbirii (cînd se rostește un enunț/sentence), timpul de referință (momentul temporal indicat de un enunț/sentence) și timpul evenimentului (momentul temporal în care s-a produs evenimentul sau starea descrisă în enunţ).

${ }^{7}$ În cartea ei despre DIL, Ehrlich (1990) pornește de la o asumpție similară.

${ }^{8}$ Pentru scopurile analizei de față vom ignora distincția lui Karttunen (1991) între factive și semi-factive. De asemenea, vom opera cu noțiunea semantică de presupoziție; pentru o discuție despre aspectele pragmatice ale presupozițiilor și statutul logic problematic al acestora, vezi, spre exemplu, Karttunen (1991). 
(20) (a) Ion își dă seama că nu are dreptate.

(b) Ion nu își dă seama că nu are dreptate.

În acest exemplu, „își dă seama” presupune că „Ion nu are dreptate” este adevărat, deoarece se păstrează în cazul negării (20b). Predicatele nonfactive includ, în schimb, diferite verbe dicendi sau inchizitive (spre exemplu, a spune, a întreba), verbe creatoare de lumi (spre exemplu, a visa, a-și imagina) sau verbe psihologice (spre exemplu, a crede, a se îndoi) (vezi de asemenea Karttunen, 1991 în legătură cu categoriile de verbe care acceptă complemente); ele nu presupun adevărul complementelor lor. Asumpția noastră este că în cazul factivelor propoziției exprimate de DIL i se atribuie o valoare semantică într-o lume a ficțiunii; în cazul nonfactivelor însă, DIL i se atribuie o valoare semantică relativă la alte lumi sau alte momente, cum ar fil lumi accesibile dintr-o lume a ficțiunii.

Pe baza considerațiilor de mai sus, propunem în cele ce urmează o reprezentare formală a perspectivei duale exprimate de DIL (aceea a personajului și aceea a naratorului), pornind de la un exemplu (21) selectat din Women in Love „Femei îndrăgostite” (Lawrence, 1977, p. 216). Operăm cu cadrul semantic schițat mai sus şi coordonate redefinite în raport de circumstanțele din lumile ficțiunii sau lumile (periferice) accesibile din lumile centrale ale ficțiunii.

(21) [a] Tomorrow was Monday. [b] Monday, the beginning of another school-week! [a] „Mîine urma să fie luni.” [b] „Luni, începutul unei alte săptămîni de școală!”

În acest exemplu, perspectiva duală în DIL poate fi probată prin specificarea valorilor a trei expresii din propoziția [a]: tomorrow „mîine”; was „urma să fie”/,va fi”, literal, „,era”, un verb la timpul trecut; și Monday „luni”. Pentru o interpretare adecvată, această propoziție reclamă postularea unei expresii parantetice care conține un predicat non-factiv, spre exemplu, Ursula thought "gîndi Ursula”, unde Ursula este personajul protagonist. Deoarece predicatul parantetic thought "gîndi” nu presupune adevărul propoziției redactate în DIL - complement semantic al acestui predicat-în lumea în care se produce enunțul, ci într-o lume în care se actualizează ceea ce gîndește personajul, lui tomorrow „mîine” i se atribuie o valoare prin formula

(22) $[[\text { tomorrow „mîine” }]]^{M, g, w_{2}, t_{2}}$ [unde $w_{2}$ este o lume compatibilă cu ceea ce gîndește protagonista, iar $t_{2}$ momentul temporal al reflecției protagonistei (anterior timpul relatării, $t_{1}$ ); cu alte cuvinte, valoarea lui tomorrow depinde de punctul de vedere al personajului, ea este atribuită într-o lume contemplată de către personaj]

Celei de a doua expresii, was „era/urma să fie”, i se atribuie o valoare prin formula

(23) $[[\text { was „era” }]]^{M, g, w_{1}, t_{1}}$ [unde $w_{1}$ este lumea centrală a ficțiunii, iar $t_{1}$ este timpul relatării (prezent), care ancorează timpul trecut al acestui verb; valoarea este atribuită într-o lume a ficțiunii descrisă de narator]

A treia expresie, Monday „luni”, primește o valoare prin formula

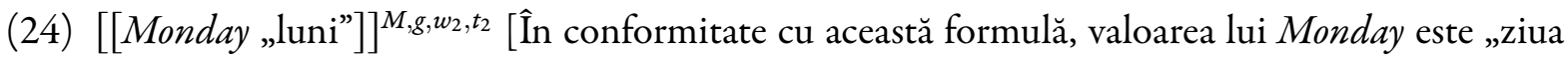
care urmează intervalului ce îl conține pe $t_{2}$ ”- unde $t_{2}$ este momentul reflecției protagonistei-, zi care poartă numele de Monday „luni”; momentul $t_{2}$ îl precedă pe $t_{1}$, timp al actului de relatare al naratorului.]

Dovada vocii/perspectivei duale în acest fragment de discurs este dată de faptul că verbul was „era/urma să fie"-la timpul trecut în limba engleză—este dependent de momentul relatării, $t_{1}$, care îl ancorează, și este, deci, despre o lume în care se actualizează ceea ce povestește naratorul, pe cînd valorile cuvintelor tomorrow și Monday sînt dependente de un timp $t_{2}$, al reflecției protagonistei $\left(t_{2}<t_{1}\right)$, și denotă un interval sau o zi, care poartă numele Monday „luni”, dintr-o lume $w_{2}$, compatibilă cu reflecția. În consecință, DIL din [a] este despre două lumi: o lume compatibilă cu ceea ce gîndește protagonista și o lume a povestirii, despre care relatează naratorul (vezi Figura 2, care ilustrează faptul că denotația DIL se regăsește în intersecția celor două lumi). 


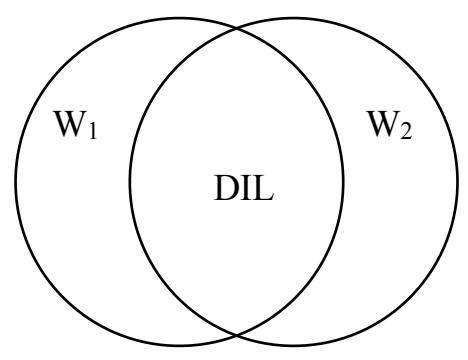

Figura 2

\section{Concluzii}

Analiza semantică de pe pozițiile lumilor posibile furnizează dovezi ale vocii sau perspectivei duale exprimate de DIL, alături de perspectiva personajului fiind prezentă și perspectiva naratorului. Analiza indică, pe această cale, că DIL, ca mod al dualității, descrie două lumi, și anume o lume compatibilă cu ceea ce gîndește sau contemplă personajul și o lume a ficțiunii, despre care relatează naratorul.

\section{Bibliografie}

Bakhtin, M. [V. N. Voloshinov] (1973). Marxism and the Philosophy of Language, Seminar Press, New York - London, CrossRef.

Banfield, A. (1982). Unspeakable Sentences, Routledge and Kegan Paul, London, CrossRef.

Chierchia, G. \& McConnell-Ginet, S. (2000). Meaning and Grammar: An Introduction to Semantics, MIT Press, Cambridge, MA.

Cohn, D. (1978). Transparent Minds, Princeton University Press, Princeton, NJ.

Currie, Gr. (1990). The Nature of Fiction, Cambridge University Press, Cambridge, CrossRef.

Doron, E. (1991). Point of View as a Factor of Content, în „Proceedings from Semantics and Linguistic Theory”, I, Cornell Working Papers in Linguistics 10, p. 51-64, CrossRef.

Ehrlich, S. (1990). Point of View: A Linguistic Analysis of Literary Style, Routledge, London - New York, CrossRef.

Fleischman, S. (1990). Tense and Narrativity: From Medieval Performance to Modern Fiction, Routledge, London - New York.

Flundernik, M. (1999). The Fictions of Language and the Languages of Fiction. The Linguistic Representation of Speech and Consciousness, Routledge, London - New York, CrossRef.

Karttunen, L. (1991). Presupposition and Linguistic Context, în Steven Davis (ed.), Pragmatics. A Reader, Oxford University Press, New York - Oxford, p. 406-415 (first edition: 1974), CrossRef.

Kiparsky P. \& Kiparsky, C. (1971). Fact, în Danny D. Steinberg \& Leon A. Jakobovits (eds.), Semantics. An Interdisciplinary Reader in Philosophy, Linguistics and Psychology, Cambridge University Press, Cambridge, p. 345-369 (first edition: 1970), CrossRef.

Kuno, S. (1986). Blended Quasi-Direct Discourse in Japanese, paper presented at the Second SDF Workshop in Japanese Syntax, Stanford University.

Kuroda, S.Y. (1976). Reflections on the Foundations of Narrative Theory, în T. A. van Dijk (ed.), Pragmatics of Language and Literature, North Holland, Amsterdam, p. 107-140.

Lawrence, D. H. (1934). The Rainbow, The Albatros, Hamburg - Paris - Bologna (first edition: 1915), CrossRef.

Lawrence, D. H. (1977). Women in Love, Penguin Books, Harmondsworth (first edition: 1921),

Lessing, D. (1981). To Room Nineteen, în R. V. Cassil (ed.), The Norton Anthology of Short Fiction., W. W. Norton \& Company, New York - London (first edition: 1963).

Lewis, D. (1979). Possible worlds, în Loux, 1979, p. 182-189 (first edition: 1973).

Lewis, D. (1983). Truth in Fiction, în David Lewis, Philosophical Papers, vol. I, Oxford University Press, New York - Oxford, p. 261-280 (first edition: 1978), CrossRef.

Loux, M.J. (1979). The Possible and the Actual: readings in the metaphysics of modality, Cornell University Press, IthacaLondon.

McHale, B. (1978). Free Indirect Discourse: A Survey of Recent Accounts, PTL, 3(2), p. 249-287.

McHale, B. (1983). Unspeakable Sentences, Unnatural Acts: Linguistics and Poetics Revisited, în „Poetics Today”, 4(1), p. 17-45, CrossRef.

Oltean, Șt. (1993). A Survey of the Pragmatic and Referential Functions of Free Indirect Discourse, inn „Poetics Today”, 14(4), p. 691-714, CrossRef. 
Oltean, Șt. (2003). On the bivocal nature of free indirect discourse, în „Journal of Literary Semantics”, 32, p. 167-176, CrossRef. Pavel, Th. G. (1986). Fictional Worlds, Harvard University Press, Cambridge, MA - London.

Portner, H. P. (2005). What is Meaning? Fundamentals of Formal Semantics, Blackwell, Oxford.

Ramazani, Vaheed (1988). The Free Indirect Mode: Flaubert and the Poetics of Irony, University Press of Virginia, Charlottesville. Rescher, Nicholas (1979). The Ontology of the Possible, în Loux, 1979, p. 166-181 (first edition: 1973).

Ron, M. (1981). Free Indirect Discourse, Mimetic Games and the Subject of Fiction, în „Poetics Today”, 2(2), p. 17-39, CrossRef. Ryan, Marie-Laure (1991). Possible Worlds, Artificial Intelligence, and Narrative Theory, Indiana University Press, Bloomington - Indianapolis.

Strauch, G. (1974). De quelques interpretations récentes du style indirect libre, în „Recherches Anglaises et Américaines”, 7, p. 4073.

Tarski, A. (1956). Logic, Semantics, Mathematics, Clarendon Press, Oxford.

Weinberg, H.H. (1981). Irony and "Style Indirect Libre” in Madame Bovary, în „Canadian Review of Comparative Literature”, $8(1)$, p. $1-9$.

Weinberg, H.H. (1984). Centers of Consciousness Reconstructed, în „Poetics Today”, 5(4), p. 767-773, CrossRef.

Woolf, V. (1964). Mrs Dalloway, Penguin Books, Harmondsworth (first edition: 1925).

Woolf, V. (1932). To the Lighthouse, The Albatros, Hamburg - Paris - Milano (first edition: 1927). 